\title{
The use of fynbos fragments by birds: Stepping-stone habitats and resource refugia
}

\begin{tabular}{|c|c|}
\hline $\begin{array}{l}\text { Authors: } \\
\text { Rory N. Sandb } \\
\text { Nicky Allsopp } \\
\text { Karen J. Esler }\end{array}$ & $\operatorname{erg}^{1}$ \\
\hline $\begin{array}{l}\text { Affiliations: } \\
\text { Department } \\
\text { Ecology and } E \\
\text { Stellenbosch } \\
\text { South Africa }\end{array}$ & $\begin{array}{l}\text { of Conservation } \\
\text { ntomology, } \\
\text { Jniversity, }\end{array}$ \\
\hline $\begin{array}{l}{ }^{2} \text { Fynbos Node } \\
\text { Environmenta } \\
\text { Network, Sou }\end{array}$ & $\begin{array}{l}\text { South African } \\
\text { I Observation } \\
\text { th Africa }\end{array}$ \\
\hline $\begin{array}{l}{ }^{3} \text { Centre for In } \\
\text { Stellenbosch } \\
\text { South Africa }\end{array}$ & $\begin{array}{l}\text { Iasion Biology, } \\
\text { Jniversity, }\end{array}$ \\
\hline $\begin{array}{l}\text { Correspondin } \\
\text { Karen Esler, kj }\end{array}$ & $\begin{array}{l}\text { g author: } \\
\text { e@sun.ac.za }\end{array}$ \\
\hline $\begin{array}{l}\text { Dates: } \\
\text { Received: } 11 \\
\text { Accepted: } 07 \\
\text { Published: } 31\end{array}$ & $\begin{array}{l}\text { May } 2015 \\
\text { Dec. } 2015 \\
\text { Mar. } 2016\end{array}$ \\
\hline $\begin{array}{l}\text { How to cite th } \\
\text { Sandberg, R.N } \\
\text { Esler, K.J., } 201 \\
\text { fynbos fragme } \\
\text { Stepping-ston } \\
\text { resource refug } \\
\text { 58(1), a1321. } \\
\text { org/10.4102/l } \\
\text { v58i1.1321 }\end{array}$ & $\begin{array}{l}\text { is article: } \\
\text {., Allsopp, N. \& } \\
\text { 6, 'The use of } \\
\text { nts by birds: } \\
\text { e habitats and } \\
\text { ia', Koedoe } \\
\text { http://dx.doi. } \\
\text { koedoe. }\end{array}$ \\
\hline $\begin{array}{l}\text { Copyright: } \\
\text { @ 2016. The } A \\
\text { Licensee: AOS } \\
\text { is licensed unc } \\
\text { Creative Comr } \\
\text { Attribution Lic }\end{array}$ & $\begin{array}{l}\text { uthors. } \\
\text { IS. This work } \\
\text { ler the } \\
\text { nons } \\
\text { ense. }\end{array}$ \\
\hline Read online: & \\
\hline 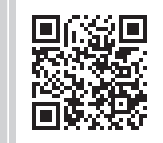 & $\begin{array}{l}\text { Scan this QR } \\
\text { code with your } \\
\text { smart phone or } \\
\text { mobile device } \\
\text { to read online. }\end{array}$ \\
\hline
\end{tabular}

Authors:

Karen J. Esler ${ }^{13}$

Affiliations:

.

Stellenbosch University,

South Africa

Network, South Africa

South Africa

Corresponding author:

Karen Esler, kje@sun.ac.za

Accepted: 07 Dec. 2015

Published: 31 Mar. 2016

How to cite this article:

Sandberg, R.N., Allsopp, N. \& fynbos fragments by birds: Stepping-stone habitats and resource refugia', Koedoe org/10.4102/koedoe. v58i1.1321

Copyright:

(C) 2016. The Authors. is licensed under the

Creative Commons

Attribution Lice

mobile device
Fynbos habitats are threatened by fragmentation through land use and anthropogenic changes in fire regimes, leading to a loss of suitable habitat for birds. We investigated the response of fynbos-typical avifauna to fragmentation and postfire vegetation age in order to better understand the consequences of these processes for bird communities. Vegetation composition and bird inventory data were collected along wandering transects in three South Outeniqua Sandstone Fynbos habitat configurations: fragmented patches (associated with anthropogenically driven habitat loss $<150$ years ago), naturally isolated fynbos islands (formed through climate-driven forest expansion in the Holocene) and extensive areas of relatively pristine habitat known as 'mainland'. The latter configurations served as references against which to investigate bird and vegetation responses to more recent habitat fragmentation. Linear regressions were used to compare the relationships of a number of bird and plant species to areas between each habitat configuration. Bird attribute frequency data were compared between habitat configurations using chi-square tests. Birds and plants showed significant species-area relationships in natural island and mainland sites, but no such relationship occurred in artificial fragments for birds, where the surrounding anthropogenic land uses are likely to have contributed generalist or colonist species. Avifaunal migratory groups were not affected by isolation distances of $>10 \mathrm{~km}$ in this study and their frequencies were the same across the three habitat configurations. Certain feeding guilds did, however, respond to postfire vegetation age, with nectarivore species twice as likely to occur in oldgrowth mainland fynbos. Fragmentation can alter fire disturbance regimes, which in turn alter the availability of resources in a habitat, so the impacts of fragmentation on birds are probably indirect through changes in the vegetation component.

Conservation implications: Fragments of South Outeniqua Sandstone Fynbos have value as resource refugia and 'stepping-stone' reserves for avifauna. Fragments should be managed for vegetation age to ensure that at least some patches sustain high levels of nectarproducing plant species. Fire management should, however, factor in both plant and bird requirements.

\section{Introduction}

Habitat loss and fragmentation pose a major threat to biodiversity globally (Saunders, Hobbs \& Margules 1991). Remaining habitat fragments are characterised by reduced effective habitat area, increased isolation from neighbouring fragments or source populations and a surrounding human-modified matrix, which reduces connectivity for some species (Saunders et al. 1991; Ricketts 2001; Fahrig 2003). Many studies have explored the negative aspects of habitat fragmentation and suggest that fragments do not provide optimal habitat for biodiversity (Fahrig 2003). Fewer studies highlight the conservation value of fragments (Turner \& Corlett 1996) or their value as 'stepping-stone' habitats to improve connectivity for motile and wide-ranging taxa such as avifauna (MacArthur \& Wilson 1967; Gilpin 1980). This leads to the question: what determines species richness in these fragments?

The extent to which fragmented communities resemble island communities, and respond according to the assumptions of island biogeography theory (MacArthur \& Wilson 1967) and subsequent metapopulation theory (Hanski \& Gilpin 1991), may depend on the nature of the community in question. Island biogeography theory dictates that island size and isolation govern rates of extinction and immigration in isolated communities and thus determine the equilibrium level of species richness on an island. Motile species, such as birds, have the capacity to use habitat fragments according to island biogeography theory principles; their rates of immigration and local extinction constituting a true equilibrium when external or anthropogenic influences are excluded. However, if some component of their habitat is dynamic, such as the temporal turnover 
of plant species in fire-adapted fynbos shrublands (Thuiller et al. 2007), then the system might not be in equilibrium, and species richness may fluctuate in relation to such spatial or temporal drivers.

Patch area is often the primary constraint affecting motile species in habitat fragments, ahead of factors such as isolation and matrix composition (e.g. Bender, Contreras \& Fahrig 1998; Ferraz et al. 2007). Species-area curves that represent this relationship are therefore frequently used in conservation planning to establish minimum critical reserve size (e.g. Bond, Midgley \& Vlok 1988; Cowling \& Bond 1991; Rybicki \& Hanski 2013). It may, however, be insufficient to base management decisions on species-area relationships alone considering that spatio-temporal aspects of isolation and the composition of the surrounding matrix can both exert a secondary influence on fragment communities (Saunders et al. 1991; Fahrig 2003). Island biogeography theory does not account for the effect of the human land-use matrix that typically surrounds fragments (Mendenhall et al. 2014), or for the time elapsed since fragment isolation (Cook, Lane \& Holt 2002; Saunders et al. 1991). The surrounding matrix may introduce invasive species (Saunders et al. 1991; Buckley et al. 2006) and novel disturbances (Saunders et al. 1991; Brotons, Mönkkönen \& Martin 2003) to a fragment as well as alter the natural disturbance regime (Bond et al. 1988; Baker 1994; Mack \& D'Antonio 1998).

Recently fragmented communities often undergo delayed extinctions, a phenomenon known as extinction debt (Tilman et al. 1994). Quantification of extinction debt allows a better understanding of the full conservation implications of habitat fragmentation, providing conservationists with an opportunity to intervene before extinction occurs (Jackson \& Sax 2009; Kuussaari et al. 2009; Wearn, Reuman \& Ewers 2012). Ecological relaxation is the term used to describe the loss of species (often with a lag period) during the process of habitat fragmentation and isolation (Vellend et al. 2006).

The Cape Floristic Region is a biodiversity hotspot in South Africa (Myers et al. 2000) containing exceptionally high botanical diversity (Rebelo et al. 2006) and ecologically important bird species (Geerts, Malherbe \& Pauw 2012; Johnson 1992). South Outeniqua Sandstone Fynbos (Rebelo et al. 2006) communities are threatened with fragmentation by urban development, agriculture, plantation forestry and the spread of invasive alien plants (Rouget et al. 2003; Rebelo et al. 2006). Fynbos avifauna may well be affected by degradation of habitat quality brought about through changes in climate (Huntley \& Barnard 2012; Chalmandrier et al. 2013) and fire regimes (Martin \& Mortimer 1991; Geerts et al.2012; Chalmandrier et al.2013). Nectarivores in particular require mature, flowering plants from which to forage and are known to migrate locally in pursuit of this resource (Rebelo 1987; Johnson 1992; Fraser 1997; Cotton 2007). Birds have been shown to be more sensitive to habitat quality than other variables, including fragment area, in urban fynbos fragments and their matrix types (Dures \& Cumming 2010).
The unique habitat mosaic associated with South Outeniqua Sandstone Fynbos provides an opportunity to evaluate the response of fynbos-typical avifauna to various aspects of habitat fragmentation. Habitat fragments that remain following habitat loss are termed 'artificial fragments' in this study, owing to their anthropogenic origin. We differentiate them from the fynbos habitat islands, which were formed naturally through climate-driven forest expansion in the early Holocene and which are found in the same area (Bond et al. 1988; Midgley \& Bond 1990). The natural habitat islands, termed 'natural islands', are largely free from the confounding effects apparent in the artificial fragments, such as recent isolation age (100-150 years) and the effects of the surrounding anthropogenically modified matrix (Ewers \& Didham 2006). South Outeniqua Sandstone Fynbos also occurs as extensive mainland areas, defined as areas covering in excess of 300 ha (Bond et al. 1988). This unique habitat configuration thus provides a framework through which to determine biogeographic processes that may occur in artificial fragments and natural habitat islands (Pickett \& Thompson 1978). Whilst birds have received much attention in the fragmentation literature, most focus has been on spatial aspects of fragmentation (e.g. review by Prugh et al. 2008) and there have been limited studies in fynbos (Dures \& Cumming 2010; Geerts et al. 2012; Pauw \& Louw 2012). In particular, studies such as ours that incorporate an understanding of surrounding matrix influences and temporal scales are rare but valuable, in that they provide a more mechanistic understanding of the factors and processes maintaining diversity in human-modified landscapes.

We compared the number of fynbos-typical bird species across three South Outeniqua Sandstone Fynbos habitat configurations to assess the response of birds to habitat fragmentation. Naturally isolated fynbos islands and extensive mainland areas served as references against which to investigate bird responses to more recent anthropogenically driven habitat fragmentation; this comparison allowed us to look for signs of extinction debt in fragmented communities. Specifically, we explored the degree to which landscape variables (location, patch or island size and nature of the surrounding matrix) explained functional and species composition. We compared the bird species data to those of the vegetation and investigated the effect of vegetation quality, using the surrogate of postfire vegetation age, on fynbos-typical bird communities and their functional trait groupings. Given that birds are relatively more motile than many plant species and can therefore avoid disturbances, we predicted slower ecological relaxation (loss of species) and lingering extinction debt in the fragment avian communities than the vegetation.

\section{Methods \\ Study area and site selection}

Bird and plant data were collected from nine natural fynbos island sites, 16 anthropogenically formed artificial fragment sites and three mainland sites. Natural island habitats were 
isolated from the mainland in the early Holocene (Midgley \& Bond 1990), and artificial fragments were isolated between 100 and 150 years ago through afforestation (Kraaij \& Van Wilgen 2011). The islands are largely surrounded by an indigenous afrotemperate forest matrix and the fragments by a plantation, farmland matrix or a combination of these and indigenous forest. Collectively, the islands, fragments and mainland plots are referred to as 'habitat configurations'.

Study sites were situated in the Garden Route National Park and on private farmland lying within: $22^{\circ} 51^{\prime} 57.02^{\prime \prime} \mathrm{E}-$ $23^{\circ} 14^{\prime} 24.09^{\prime \prime} \mathrm{E} / 33^{\circ} 53^{\prime} 2.58^{\prime \prime S}-34^{\circ} 4^{\prime} 41.92^{\prime \prime} \mathrm{S}$ in an elevation range of between $500 \mathrm{~m}$ and $1500 \mathrm{~m}$. A detailed description of the study area can be found in Bond et al. (1988), Rebelo et al. (2006), and Sandberg (2013), with further information on sites provided in Appendices 1 and 2.

The landscape features of each site were calculated using Google Earth Pro on 2011 images. Isolation distance of natural fynbos islands and artificial fragments was calculated as the straight-line distance from the centre of the site to the perimeter of the nearest area of mainland fynbos. Percentage matrix edges were calculated for the three dominant matrix types in the study area: forest, farm and plantation. Matrix heterogeneity was calculated as the number of discrete matrix types bordering on a particular fragment (Appendices 1 and 2).

Vegetation composition was collected from each site based on the methods used by Bond et al. (1988). Wandering transects were chosen over point counts for collection of avifaunal data in order to minimise the effects of vegetation with variable density (P. Hockey, pers. comm., September 2011). The length of these transects was governed by species accumulation and ceased below a critical rate of two new discoveries per hour. For three mainland sites, vegetation and birds were counted in nested subplots of increasing size ( 1 ha; 2 ha; 4 ha; 6 ha; 10 ha; 15 ha; 20 ha; 25 ha; 35 ha; 50 ha; 75 ha; 110 ha). Amongst these subplots, most had been burnt 3 years ago whilst 10 retained 75 -year-old vegetation. All data were collected between September 2011 and January 2012 for standardisation. Bird data collection commenced after sunrise and ceased before 14-15 hours, on days of moderate temperatures and calm conditions (Lipsey \& Hockey 2010). Birds were counted along wandering transects to remove any bias introduced by vegetation heterogeneity or age (P. Hockey, pers. comm., September 2011). The length of these transects varied with patch size and with vegetation density and was governed by bird species accumulation. When the discovery rate of bird species dropped to below two new species per hour, the sampling was considered complete. Field identification of species was complemented by ex situ identification using photographs and call recordings. T. Kraaij provided historic fire data, courtesy of South African National Parks.

Avifauna were defined either as fynbos-typical birds or matrix-typical birds (those known to not use fynbos habitat) as classified by Hockey, Ryan and Dean (2005). Additionally, we classified birds according to their feeding guilds (frugivore, generalist, nectarivore, granivore, carnivore and insectivore) and migratory behaviour (resident, altitudinal migrant, intra-African migrant, nomad, some local movement).

The relationship of number of bird species to area was compared between the three habitat configurations using linear regressions to investigate area effects and extinction debt. The influence of postfire vegetation age was standardised by including only a subset of sites with a postfire age of 20 or more years in the regression analyses. This removed one young natural island and four artificial islands from the regression analyses. Comparisons were run between the avifaunal regression curves and those of the vegetation community for each habitat configuration to determine if the avifaunal response to reduced area in the artificial fragments is comparable to that in the natural islands and in the mainland and to the response of the vegetation community.

Avifaunal connectivity was indirectly assessed by comparing the proportion of bird species in different feeding guilds and migratory groups (Hockey et al. 2005), between the habitat configurations in modified chi-square tests as used by Bond et al. (1988). In these tests, the mainland data were used to calculate the expected value in the natural islands and the artificial fragments, and natural island data were used in comparison between natural islands and artificial fragments. The proportion of each functional trait group was calculated relative to the artificial fragment or natural island species total. These tests adopt the null hypothesis that the frequencies in each functional trait group do not differ between the observed and the expected value. Modified chisquare tests were also used to determine the influence of matrix heterogeneity surrounding artificial fragments on the distribution of feeding guilds and migratory groups. Matrix heterogeneity was measured as the number of discrete matrix types that form an edge directly with the artificial fragment in question. Only fynbos-typical bird species were included in these analyses.

The effect of postfire vegetation age on various bird feeding guilds was investigated descriptively using young (burned within 10 years of study) and old (burned over 20 years ago) growth mainland habitat.

\section{Results}

\section{Species-area relationships}

Positive relationships between species number and area were found for birds and plants in natural islands and mainland fynbos (Figure 1). Artificial fragments showed no relationship between area and species number (birds: $r^{2}=0.01, P=0.67$, vegetation: $r^{2}=0.21, P=0.07$ ) (Figure 1 ).

The species-area slopes for mainland and natural islands were similar for plants $(P>0.05)$ and birds $(P>0.05)$ (Figure 1), although the avian species-area curves have 


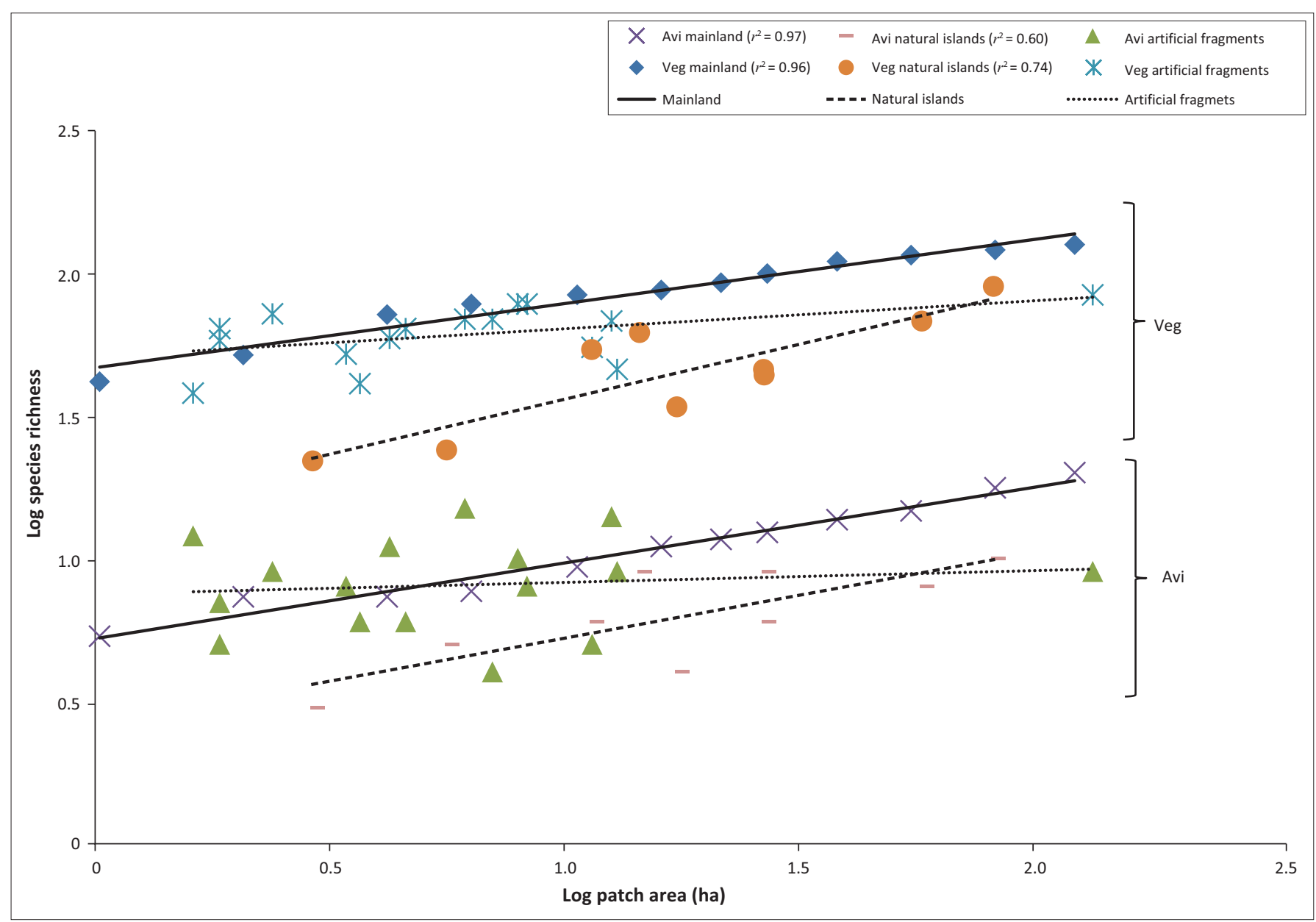

Note: Vegetation data included fynbos and forest margin species only. Avifaunal data only included bird species identified by Hockey et al. (2005) as using fynbos to some degree, as opposed to not at all. Mainland data are represented by an average of the three accumulation series. All natural island and mainland species-area regressions are significant $(P<0.05)$. Only 8 of 9 natural island plots and 12 of 16 AF plots were included in the regression analysis in order to standardise for postfire age.

FIGURE 1: Relationship of species number of avifauna and vegetation to area in the three fynbos habitat configurations, using logged data.

lower Y-intercepts (Figure 1). This can be attributed to the relative size of the two species pools; a total of 488 plant species were observed in the study, compared to 87 bird species, of which 370 and 45 , respectively, were classified as fynbos-typical.

\section{Connectivity and matrix effects}

The frequency of migratory avifaunal groups did not differ significantly between the three fynbos habitats when analysed with a modified chi-square test using fynbos-typical bird data (data not shown).

Insectivores made up the biggest feeding guild of birds in all habitats (Figure 2). There were few significant differences in the proportion of individual feeding guilds found on different habitat configurations (Figure 2, Table 1) but the Cape sugarbird (Promerops cafer), an important fynbos nectarivore, was present in the mainland areas but absent from both the artificial fragments and the natural islands. Frugivores were overrepresented and granivores underrepresented in the natural islands relative to the mainland. The feeding guild frequencies between the natural islands and the artificial fragments were not significantly different (Figure 2, Table 1). Modified chi-squared tests indicated that there was no statistically significant difference in the relative occurrence of birds belonging to certain feeding and movement guilds in artificial fragments that differed in the heterogeneity of the surrounding matrix.

\section{Postfire vegetation age}

In the absence of confounding fragmentation effects, three of the mainland avifaunal feeding guilds clearly responded to postfire vegetation age (Figure 3). A qualitative assessment suggests proportionally more generalist and granivore bird species in mainland fynbos that had been burned within the past 10 years than in fynbos that is over 20 years old. Nectarivore species are relatively more abundant in the older growth fynbos than in the recently burned areas, suggesting a positive association between nectarivore richness and postfire vegetation age. Only four artificial fragments and part of one natural island were younger than 20 years.

\section{Discussion}

We investigated the response of avifauna to the fragmentation of South Outeniqua Sandstone Fynbos habitat and found that birds are relatively resilient to fragmentation effects. Despite most of the artificial fragments being in existence 


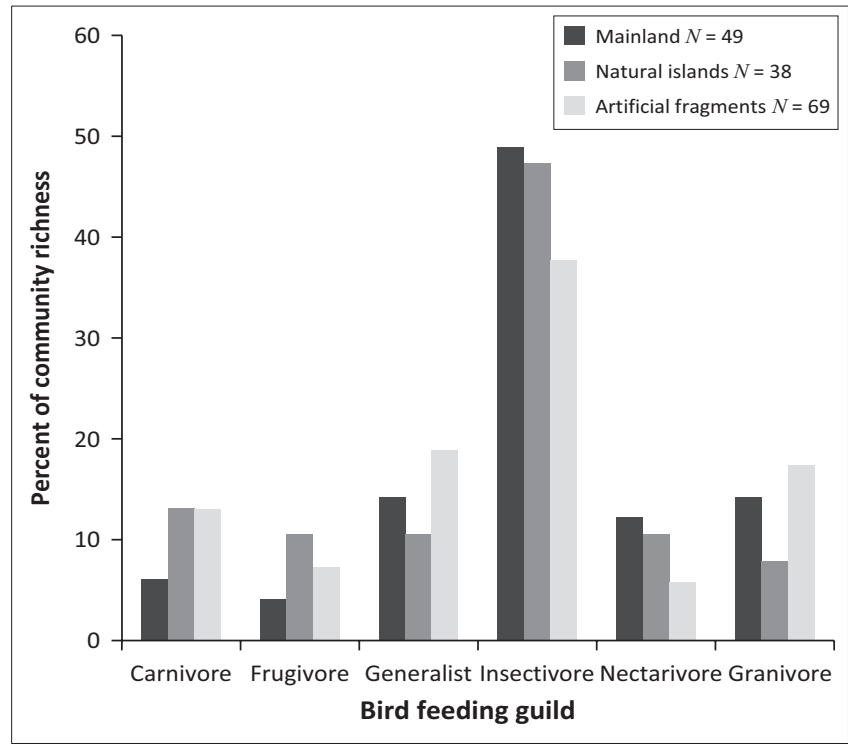

$N$, total species counts for each habitat.

FIGURE 2: The percentage contribution of each bird feeding guild to the total species richness of the three fynbos configurations: mainland, natural islands and artificial fragments.

TABLE 1: Results from modified chi-squared tests of avifaunal feeding guild distributions between the different habitat configurations.

\begin{tabular}{lccccc}
\hline Configuration & Group & $\boldsymbol{P}$-value & $\chi^{2}$-value & Increase & Decrease \\
\hline $\mathrm{ML}$ v AF & All & NS & 12.37 & - & - \\
$\mathrm{ML}$ v NI & All & $*$ & 15.71 & Frugivore & Granivore \\
$\mathrm{ML}$ v NI & Proximate & $*$ & 16.58 & Frugivore & Predator \\
$\mathrm{ML}$ v AF & Distant & NS & 12.37 & - & - \\
$\mathrm{ML}$ v NI & Distant & NS & 3.97 & - & - \\
$\mathrm{NI}$ v AF & All & NS & 4.65 & - & - \\
$\mathrm{NI}$ v AF & Distant & $*$ & 1.75 & Granivore & Nectarivore \\
\hline
\end{tabular}

Note: In the first five tests, mainland data were used to calculate the expected value. In the last two tests, natural island data were used to calculate the expected value. 'Proximate' patches are isolated by less than $2000 \mathrm{~m}$. 'Distant' patches are isolated by more than 2000 $\mathrm{m}$. 'All' refers to all patches, irrespective of isolation distance. NS $=P>0.05 ;{ }^{*} P<0.05$ 'Increase' and 'Decrease' show the overrepresentation and underrepresentation of feeding guilds, respectively.

$\mathrm{ML}$, mainland; $\mathrm{NI}$, natural islands; $\mathrm{AF}$, artificial fragments.

for more than 100 years, they did not show the same relationship as natural islands where birds showed significant species-area relationships with species number decreasing as size decreased, similar to that observed in the vegetation community.

We then tested the response of different avifaunal migratory groups and feeding guilds to habitat configuration and the surrounding matrix habitat composition in order to indirectly assess connectivity in the fragments. Migratory groups are not affected by isolation distances experienced in this study $(<10 \mathrm{~km})$, and their frequencies remain the same across the three habitat configurations. However, feeding guilds did vary between habitat configurations under certain conditions. We further investigated the response of avifauna to postfire vegetation age and found that this differs between bird feeding guilds. These results suggest that artificial fragments of South Outeniqua Sandstone Fynbos may have value as resource refugia and 'stepping-stone' reserves for avifauna under the pressures of habitat fragmentation and changing fire regimes.

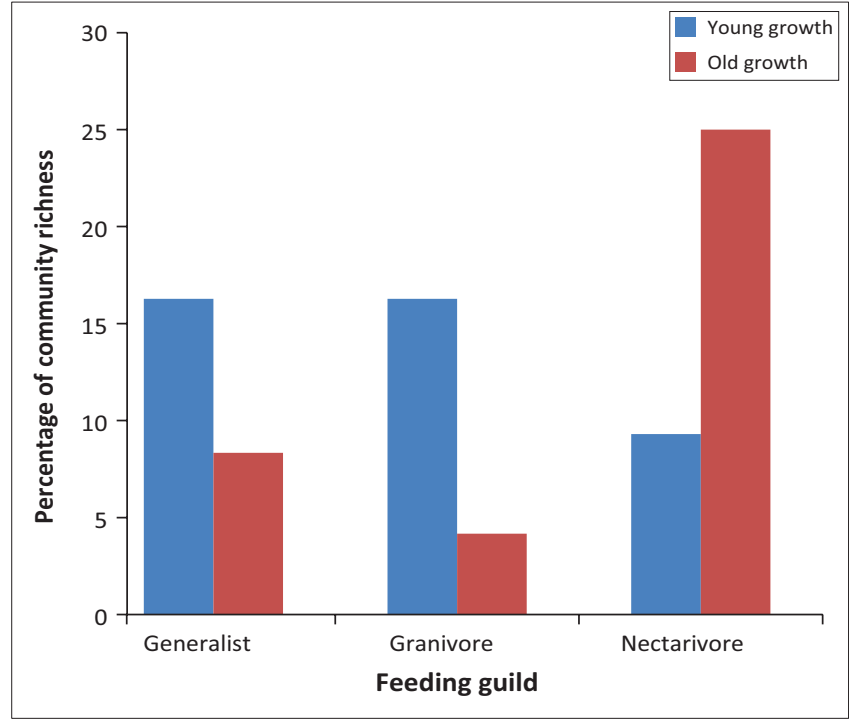

Note: Young growth $(N=26)$ and old-growth $(N=10)$ mainland sites were used, denoting fynbos burned within 10 years and fynbos burned over 20 years before the study, respectively.

FIGURE 3: The response of three bird feeding guilds to postfire age in the mainland plots shown with percentage of community richness data.

\section{Species-area considerations}

The positive relationship between bird species and area in the natural islands is typical of isolated biotic communities (Dengler 2009; Kuussaari et al. 2009). The slope of the avifaunal species-area response curve did not differ from that of the vegetation community in island and mainland habitat configurations; only the Y-intercept did. Neither the bird nor vegetation communities in the artificial fragments showed a relationship between fragment size and species number. This indicates that biological communities that differ in the size of their species source pools and their motility (birds can migrate to and from a fragment more easily than plants) can share a similar response to artificially reduced fragment area. These patterns are somewhat contrary to our predictions of slower ecological relaxation and lingering extinction debt in the relatively motile avian communities than the plant communities, suggesting that extinction debt is not currently being 'paid' in these bird communities. This would have been shown by a species-area relationship 'intermediate' to that of the natural islands and the mainland (Kuussaari et al. 2009). Our results suggested that the species richness of birds in the artificial fragments does not represent a stable equilibrium, and, in many of the fragments, species number exceeds that of the mainland fynbos. Although the natural island habitat data suggest that birds are under area-based extinction debt (and respond primarily to the effect of area on vegetation richness), the elevated bird richness in the artificial fragments may be attributed to favourable conditions that are provided by the surrounding matrix to generalist or colonist species. Thus, through this non-area-based 'immigration credit' (Jackson \& Sax 2009), the area-based extinction debt is cancelled out. Of course, these improved bird habitat conditions that we propose in the artificial fragments may be temporary and change as negative fragmentation effects (e.g. loss of plant species providing specialist avifaunal diets) increase. 
The natural island data suggest that the artificial fragment bird communities will probably also experience further areabased extinctions in the future as the debt that exists in the vegetation community is 'paid' off. Other studies have found fragment area to be of secondary importance in determining avian response after the influence of habitat quality or fragment geometry (Dean \& Bond 1994; Lees \& Peres 2006) and similarly for bats where the quality of the matrix is a major determinant (Mendenhall et al. 2014).

\section{Connectivity}

Connectivity was not significantly reduced by the nature of the surrounding matrix because the migratory group frequencies in the artificial fragments were not influenced by the number of matrix types that surround a fragment. These frequencies also remained constant in the artificial fragments, surrounded by heterogeneous matrix, relative to the mainland and the natural island frequencies. Local migrant species are present in the artificial fragments in proportionally similar numbers to those in the mainland (data not shown), which suggests that avifaunal groups known to migrate naturally and will continue to migrate to or from artificial fragments.

The feeding guild frequencies in the artificial fragments, nectarivores included, remained consistent with those in the mainland sites throughout, suggesting that fynbostypical birds are largely capable of local migration across afrotemperate forest and the human land-use matrix. Nectarivores are important pollinators of fynbos vegetation (Rebelo 1987; Johnson 1992; Le Maitre \& Midgley 1992). Previous studies have found nectarivores to migrate locally whilst tracking availability of their nectar resource (Johnson 1992; Fraser 1997; Cotton 2007). Fynbos-typical nectarivores often migrate along altitudinal gradients in search of nectaryielding flowers which become seasonally available at different altitudes (Siegfried 1983; Rebelo 1987; Johnson 1992). The absence of the Cape sugarbird (P. cafer) from all of the natural islands and artificial fragments is however highlighted because this endemic species is an important pollinator of various Proteaceae species (Martin \& Mortimer 1991; Fraser 1997; Geerts et al. 2012). Sugarbirds feed exclusively on nectar from Proteaceae flowers and on the invertebrates that are associated with these flowers (Calf, Downs \& Cherry 2003; Hockey et al. 2005). These plants were in flower during sampling. Small, isolated fynbos patches may not have the species richness of Proteaceae or the abundance of Proteaceae plants that are required by Cape sugarbirds (Nottebrock, Esler \& Schurr 2013). Alternately, sugarbird movements could be restricted by the nature of the surrounding matrix to a greater degree than other nectarivores. Sugarbirds are known to fly long distances (the furthest recorded migration being $365 \mathrm{~km}$ ); however, they seldom leave fynbos habitat (Fraser 1997; Calf et al. 2003; Hockey et al. 2005). Pauw and Louw (2012) demonstrated similar movement restrictions for malachite sunbirds in an urban setting, but this did not hold true for southern doublecollared sunbirds, which are found in all habitat types.
The overrepresentation of frugivores in natural islands is attributed to the inclusion of species, such as the African olive pigeon (Columba arquatrix) and Knysna turaco (Tauraco corythaix), both frugivores, from the indigenous forest (Phillips 1927; Manders \& Richardson 1992) that forms the dominant boundary around the islands. The significant overrepresentation of granivores in the artificial fragments relative to the natural islands is attributed to the likely presence of graminoid vegetation species in the surrounding agricultural matrix and in some of the fragments. Literature suggests that granivores in habitat fragments that are surrounded by agriculture are able to use the matrix to feed on cereal crops and graminoids (Mangnall \& Crowe 2003). It is likely that this applies to granivores in fragments of South Outeniqua Sandstone Fynbos as well. The granivore frequency in the artificial fragments did not differ from that in the mainland, and thus is not an immediate conservation concern because it does not seem to reflect a change in regional bird dynamics.

We suggest that future research should address the question of bird species connectivity with empirical evidence of bird migration at the species level. This may yield greater insights into the distribution of ecologically important species such as the Cape sugarbird. Inferences drawn from the presence or absence of specific migratory and feeding guild groups under various levels of isolation and matrix type do however address our questions concerning community dynamics.

\section{Postfire age}

Our results suggest that nectarivore presence more than doubles in old-growth mainland fynbos that has remained fire free for at least 20 years than in recently burnt fynbos sites. This is consistent with other studies that have documented increased fynbos-typical nectarivore abundance with postfire vegetation age (e.g. Chalmandrier et al. 2013). This has important conservation implications for fynbostypical nectarivores considering that there is a documented reduction of recent fire return intervals in extensive fynbos areas throughout the Cape Floristic Region (Forsyth \& Van Wilgen 2008; Southey 2009; Kraaij et al. 2012), as highlighted by Chalmandrier et al. (2013). Younger mainland fynbos (burned within the last 10 years) also contained a higher percentage of generalist and granivore species than fynbos burned 20 years or more ago. This pattern seems typical of recently burnt fynbos habitats (Chalmandrier et al. 2013).

Birds are sensitive to the quality of their habitat (Parker et al. 2005; Briggs, Seddon \& Doyle 2007) which is often linked to the quality of the vegetation community. Alien plant species capable of affecting this quality (Mack \& D'Antonio 1998) can potentially enter a habitat patch from the matrix or via avian dispersal vectors (Phillips 1927; Manders \& Richardson 1992) and should not be overlooked when considering a patch for avian conservation.

\section{Implications}

Our study shows that South Outeniqua Sandstone Fynbos avifauna is responsive to habitat fragmentation, but that even 
150 years postfragmentation, artificially created fragments still host fynbos birds. Future research should focus on how to maintain the persistence of these fragment avian communities through active management of fragment habitats. At the very least, patches should be managed for vegetation age to ensure that at least some patches sustain high levels of nectarproducing plant species. Fire management should, however, factor in both plant and bird requirements.

Their motility allows most fynbos-typical birds to migrate locally through human land-use matrixes to reach fragments of fynbos habitat which serve as stepping-stone habitats or as resource refugia to most nectarivores. The apparent response of avifauna to patch areas in natural islands mirrors the response of plant species to habitat area. The prescription of controlled fire regime to conserve the vegetation and the avifauna dependent on this in artificial fragments needs attention.

\section{Acknowledgements}

We thank the Garden Route National Park for supporting the study and granting us a research permit. Financial assistance is gratefully acknowledged from the SAEON Fynbos Node (R.N.S.), the NRF-DST Centre of Excellence for Invasion Biology (K.J.E.) and the NRF Incentive Fund (K.J.E.).

\section{Competing interests}

The authors declare that they have no financial or personal relationships which may have inappropriately influenced them in writing this article.

\section{Authors' contributions}

R.N.S. was supervised by K.J.E. and N.A. who provided input into the research design, guided statistical analysis and contributed to writing the manuscript. R.N.S. conducted the fieldwork, R.N.S., K.J.E. and N.A. analysed the data. R.N.S. wrote the first draft of the paper. K.J.E. and N.A. finalised the draft.

\section{References}

Baker, W.L., 1994, 'Restoration of landscape structure altered by fire suppression', Conservation Biology 8, 763-769.

Bender, D.J., Contreras, T.A. \& Fahrig, L., 1998, 'Habitat loss and population decline: A meta-analysis of the patch size effect', Ecology 79(2), 517-533.

Bond, W.J., Midgley, J. \& Vlok, J., 1988, 'When is an island not an island? Insular effects and their causes in fynbos shrublands', Oecologia 77(4), 515-521.

Briggs, S.V., Seddon, J.A. \& Doyle, S.J., 2007, 'Structures of bird communities in woodland remnants in central New South Wales, Australia', Australian Journal of Zoology 55(1), 29-40.

Brotons, L., Mönkkönen, M. \& Martin, J.L., 2003, 'Are fragments islands? Landscape context and density-area relationships in boreal forest birds', The American Naturalist 162(3), 343-357.

Buckley, Y.M., Anderson, S., Catterall, C., Corlett, R.T., Engel, T., Gosper, C.R. et al., 2006, 'Management of plant invasions mediated by frugivore interactions', Journal of Applied Ecology 43, 848-857.

Calf, K.M., Downs, C.T. \& Cherry, M.I., 2003, 'Territoriality of Cape Sugarbirds (Promerops cafer) between and within breeding seasons', Ostrich 74(1-2), 125-128.

Chalmandrier, L., Midgley, G.F., Barnard, P. \& Sirami, C., 2013, 'Effects of time since fire on birds in a plant diversity hotspot', Acta Oecologica 49, 99-106.

Cook, W.M., Lane, K.T. \& Holt, D., 2002, 'Island theory, matrix effects and species richness patterns in habitat fragments', Ecology Letters 5, 619-623.
Cotton, P.A., 2007, 'Seasonal resource tracking by Amazonian hummingbirds', Ibis 149(1), 135-142.

Cowling, R.M. \& Bond, W.J., 1991, 'How small can reserves be? An empirical approach in Cape Fynbos, South Africa', Biological Conservation 58, 243-256.

Dean, W.R.J. \& Bond, W.J., 1994, 'Apparent avian extinctions from islands in a manmade lake, South Africa', Ostrich 65, 7-13.

Dengler, J., 2009, 'Which function describes the species-area relationship best? A review and empirical evaluation', Journal of Biogeography 36(4), 728-744.

Dures, S.G. \& Cumming, G.S., 2010, 'The confounding influence of homogenising invasive species in a globally endangered and largely urban biome: Does habitat quality dominate avian biodiversity?', Biological Conservation 143(3), 768-777.

Ewers, R.M. \& Didham, R.K., 2006, 'Confounding factors in the detection of species responses to habitat fragmentation', Biological Review 81, 117-142.

Fahrig, L., 2003, 'Effects of habitat fragmentation on biodiversity', Annual Review of Ecology, Evolution and Systematics 34, 487-515.

Ferraz, G.N., Nichols, J.D., Hines, J.E., Stouffer, P.C., Bierregaard, R.O. Jr. \& Lovejoy, T.E., 2007, 'A large-scale deforestation experiment: Effects of patch area and isolation on Amazon birds', Science 315(5809), 238-41.

Forsyth, G.G. \& Van Wilgen, B.W., 2008, 'The recent fire history of the Table Mountain National Park, and implications for fire management', Koedoe 50, 3-9.

Fraser, M.W., 1997, 'Cape sugarbird Promerops cafer', in J.A. Harrison et al., (ed.), The Atlas of Southern African Birds. Vol. 2: Passerines, pp. 484-485, Birdlife South Africa, South Africa.

Geerts, S., Malherbe, S.D.T. \& Pauw, A., 2012, 'Reduced flower visitation by nectarfeeding birds in response to fire in Cape fynbos vegetation, South Africa', Journa of Ornithology 153(2), 297-301.

Gilpin, M.E., 1980, 'The role of stepping-stone islands', Theoretical Population Biology 17, 247-253.

Hanski, I. \& Gilpin, M., 1991, 'Metapopulation dynamics: Brief history and conceptual domain', Biological Journal of the Linnean Society 42, 3-16.

Hockey, P.A.R., Ryan, P.G. \& Dean, W.R.J., 2005, Roberts birds of Southern Africa, 7th edn., The Trustees of the John Voelcker Bird Book Fund, Cape Town, South Africa.

Huntley, B. \& Barnard, P., 2012, 'Potential impacts of climatic change on southern African birds of fynbos and grassland biodiversity hotspots', Diversity and Distributions 18(8), 769-781.

Jackson, S.T. \& Sax, D.F., 2009, 'Balancing biodiversity in a changing environment: Extinction debt, immigration credit and species turnover', Trends in Ecology and Evolution 25(3), 153-60.

Johnson, S.D., 1992, 'Plant-animal relationships', in R.M. Cowling (ed.), The ecology of fynbos. Nutrients, fire and diversity, pp. 175-205, Oxford University Press, Cape Town.

Kraaij, T., Baard, J.A., Cowling, R.M., Van Wilgen, B.W. \& Das, S., 2012, 'Historical fire regimes in a poorly understood, fire-prone ecosystem: Eastern coastal fynbos', International Journal of Wildland Fire 22, 277-287.

Kraaij, T. \& Van Wilgen, B.W., 2011, 'Past approaches and future challenges to the management of fire and invasive alien plants in the new Garden Route National Park', South African Journal of Science 107(9/10), 1-11.

Kuussaari, M., Bommarco, R., Heikkinen, R.K., Helm, A., Krauss, J., Lindborg, R. et al., 2009, 'Extinction debt: A challenge for biodiversity conservation', Trends in Ecology \& Evolution 24(10), 564-571.

Le Maitre, D.C. \& Midgley, J.J., 1992, 'Plant reproductive ecology', in R.M. Cowling (ed.), The ecology of fynbos. Nutrients, fire and diversity, pp. 135-17, Oxford University Press, Cape Town.

Lees, A.C. \& Peres, C.A., 2006, 'Rapid avifaunal collapse along the Amazonian deforestation frontier', Biological Conservation 133(2), 198-211.

Lipsey, M.K. \& Hockey, P.A.R., 2011 (actual 2010), 'Do ecological networks in South African commercial forests benefit grassland birds? A case study of a pine plantation in KwaZulu-Natal', Agriculture, Ecosystems and Environment 137, 133-142.

MacArthur, R.H. \& Wilson, E.O., 1967, The theory of island biogeography, 13th edn. Princeton University Press Princeton, NJ.

Mack, M.C. \& D’Antonio, C.M., 1998, 'Impacts of biological invasions on disturbance regimes', Trends in Ecology and Evolution 13(5), 195-198.

Manders, P.T. \& Richardson, D.M., 1992, 'Colonization of Cape fynbos communities by forest species', Forest Ecology and Management 48, 277-293.

Mangnall, M.J. \& Crowe, T.M., 2003, 'The effects of agriculture on farmland bird assemblages on the Agulhas Plain, Western Cape, South Africa', African Journal of Ecology 41, 266-276.

Martin, R. \& Mortimer, J., 1991, 'Fynbos: Too frequent burning poses threat to Cape sugarbirds', Promerops 199, 6-8.

Mendenhall, C.D., Karp, D.S., Meyer, C.F.J., Hadly, E.A. \& Daily, G.C., 2014, 'Predicting biodiversity change and averting collapse in agricultural landscapes', Nature 509 213-217.

Midgley, J. \& Bond, W.J., 1990, 'Knysna fynbos "islands": Origins and conservation', South African Forestry Journal 153, 18-21.

Myers, N., Mittermeier, R.A., Mittermeier, C.G., da Fonseca, G.A.B. \& Kent, J., 2000, 'Biodiversity hotspots for conservation priorities', Nature 403, 853-858.

Nottebrock, H., Esler, K.J. \& Schurr, F.M., 2013, 'Effects of intraspecific and community density on the lifetime fecundity of long-lived shrubs', Perspectives in Plant Ecology, Evolution and Systematics 15, 150-161.

Parker, T.H., Stansberry, B.M., Becker, C.D. \& Gipson, P.S., 2005, 'Edge and area effects on the occurrence of migrant forest songbirds', Conservation Biology 19(4), 1157-1167. 
Pauw, A. \& Louw, K., 2012, 'Urbanization drives a reduction in functional diversity in a guild of nectar-feeding birds', Ecology and Society 17(2), 27.

Phillips, J.F.V., 1927, 'The role of the 'Bush dove' Columba arquatrix T. \& K., in fruit dispersal in the Knysna forests', South African Journal of Science 24, 435-440.

Pickett, S.T.A. \& Thompson, J.H., 1978, 'Patch dynamics and the design of nature reserves', Biological Conservation 13, 27-37.

Prugh, L.R., Hodges, K.E., Sinclair, A.R.E. \& Brashares, J.S., 2008, 'Effect of habitat area and isolation on fragmented animal populations', Proceedings of the Nationa Academy of Sciences 105, 20770-20775.

Rebelo, A.G., 1987, 'Bird pollination in the Cape flora', in A.G. Rebelo, (ed.) A preliminary synthesis of pollination biology in the Cape flora, pp. 158-159, CSIR, Pretoria, South Africa.

Rebelo, A.G., Rebelo, A.G., Boucher, C., Helme, N., Mucina, L. \& Rutherford, M.C. 2006, 'Fynbos biome', in L. Mucina. \& M.C. Rutherford, (eds.), The vegetation of South Africa, Lesotho and Swaziland. Strelitzia 19. n.p., South African National South Africa, Lesotho and Swazi
Biodiversity Institute, Pretoria.

Ricketts, T.H., 2001, 'The matrix matters: Effective isolation in fragmented landscapes', The American Naturalist 158(1), 87-99.

Rouget, M., Richardson, D.M., Cowling, R.M., Lloyd, J.W. \& Lombard, A.T., 2003, 'Current patterns of habitat transformation and future threats to biodiversity in terrestrial ecosystems of the Cape Floristic Region, South Africa', Biological Conservation $112,63-85$.

Rybicki, J. \& Hanski, I., 2013, 'Species-area relationships and extinctions caused by habitat loss and fragmentation', Ecology Letters 1, 27-28.
Sandberg, R., 2013, 'The response of biological communities to natural and anthropogenic habitat fragmentation in South Outeniqua Sandstone Fynbos, South Africa', MSc Dissertation, Stellenbosch University, Stellenbosch.

Saunders, D.A., Hobbs, R.J. \& Margules, C.R., 1991, 'Biological consequences of ecosystem fragmentation: A review', Conservation Biology 5(1), 18-32.

Siegfried, W.R., 1983, 'Trophic structure of some communities of fynbos birds', Journal of South African Botany 49(1), 1-43.

Southey, D., 2009, 'Wildfires in the Cape floristic region: Exploring vegetation and weather as drivers of fire frequency', MSc Thesis, University of Cape Town, Cape Town.

Thuiller, W., Slingsby, J.A., Privett, S.D.J. \& Cowling, R.M., 2007, 'Stochastic species turnover and stable coexistence in a species-rich, fire-prone plant community', Plos One 2(9), p.e938.

Tilman, D., May, R.M., Lehman, C.L. \& Nowak, M.A., 1994, 'Habitat destruction and the extinction debt', Nature $371,65-66$

Turner, I.M. \& Corlett, R.T., 1996, 'The conservation value of small, isolated fragments of lowland tropical rain forest', Trends in Ecology \& Evolution 11(8), 330-333.

Vellend, M., Verheyen, K., Jacquemyn, H., Kolb, A., Van Calster, H., Peterken, G. et al., 2006, 'Extinction debt of forest plant persists for more than a century following habitat fragmentation,' Ecology 87 (3), 542-548.

Wearn, O.R., Reuman, D.C. \& Ewers, R.M., 2012, 'Extinction debt and windows of conservation opportunity in the Brazilian Amazon', Science 337, 228-232. 


\section{Appendix 1}

Physical characteristics of the natural islands included in the study. Sites were given unique codes that are used by SANParks. All site codes were given the prefix ' $\mathrm{NI}$ ' indicating that these areas are natural islands. Isolation distance (DTN-FY) is measured as the distance from the centre of an island to the edge of the nearest section of mainland fynbos. Postfire age categories are as follows: 1 = burnt within past 10 years; 2 = last burned between 10 and 20 years ago; $3=$ has not burned in over 20 years.

TABLE 1-A1: Physical characteristics of the natural islands included in the study.

\begin{tabular}{lccc}
\hline Site code & Area (ha) & DTN-FY (m) \\
\hline NI019 & 2.79 & 3835 & Postfire age \\
NI022 & 5.33 & 2232 & 3 \\
NI036 & 10.72 & 3858 & 3 \\
NI042 & 24.54 & 744 & 3 \\
NI043 & 13.50 & 218 & 3 \\
NI044 & 52.63 & 1027 & 301 \\
NI048 & 16.15 & 546 & 3 \\
NI050 & 74.34 & 12947 & 3 \\
NI067 & 24.60 & 3 & \\
\hline
\end{tabular}




\section{Appendix 2}

Physical characteristics of the artificial fragments included in the study. Sites were given unique codes or codes that are used by SANParks. All site codes were given the prefix 'AF' indicating that these areas are artificial fragments. Isolation distance (DTN-FY) is measured as the distance from the centre of an island to the edge of the nearest section of mainland fynbos. Matrix heterogeneity refers to the number of discrete matrix types that border a fragment. Edge percent of 'FO' (indigenous forest), 'FA' (farmland) and ' $P L^{\prime}$ (plantation and invasive alien trees) indicates the proportion of a fragment's perimeter that is shared with each of these three matrix types. Postfire age group refers to one of the three postfire age categories for fynbos vegetation. Note AF32 and 33 sites are divided by a road that results in the $\mathrm{E}$ and $\mathrm{W}$ islands. In each case, the $E$ site has been burnt more recently than the $W$ site.

TABLE 1-A2: Physical characteristics of the artificial fragments included in the study.

\begin{tabular}{|c|c|c|c|c|c|c|c|}
\hline Site code & Area (ha) & DTN-FY (m) & Matrix heterogeneity & Edge-FO (\%) & Edge-FA (\%) & Edge-PL (\%) & Postfire age group \\
\hline AF010 & 2.30 & 3922 & 3 & 53.01 & 3.07 & 43.92 & 3 \\
\hline AF011 & 7.51 & 3531 & 2 & 56.70 & 0.00 & 43.30 & 3 \\
\hline AF014 & 7.85 & 6653 & 3 & 76.59 & 16.46 & 6.96 & 3 \\
\hline AF015 & 6.65 & 7082 & 2 & 75.02 & 0.00 & 24.98 & 3 \\
\hline AF016 & 3.51 & 7888 & 2 & 54.22 & 0.00 & 45.78 & 3 \\
\hline AF032E & 3.28 & 5773 & 2 & 63.92 & 0.00 & 14.40 & 2 \\
\hline AF032W & 4.05 & 6193 & 2 & 37.92 & 39.56 & 0.00 & 3 \\
\hline AF033E & 10.74 & 6259 & 1 & 86.70 & 0.00 & 0.00 & 2 \\
\hline AF033W & 11.80 & 6510 & 2 & 85.99 & 0.00 & 0.00 & 3 \\
\hline AF040 & 119.99 & 573 & 2 & 45.26 & 0.00 & 54.74 & 1 \\
\hline AFCW & 4.38 & 6541 & 2 & 94.85 & 0.00 & 5.15 & 3 \\
\hline AFQD & 5.82 & 9785 & 3 & 19.23 & 63.95 & 0.00 & 3 \\
\hline AFTB & 1.78 & 8222 & 3 & 68.20 & 7.43 & 24.37 & 3 \\
\hline AFTD & 1.80 & 8044 & 2 & 0.00 & 3.41 & 96.59 & 3 \\
\hline AFTP & 1.57 & 6430 & 3 & 0.00 & 51.69 & 16.10 & 3 \\
\hline AFYW & 12.13 & 5630 & 3 & 70.79 & 24.85 & 4.36 & 2 \\
\hline
\end{tabular}

